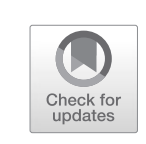

\title{
Dancing with Lava: Indigenous Interactions with an Active Volcano in Arizona
}

\author{
Katbleen Van Vlack
}

\section{INTRODUCTION}

The Little Springs Lava Flow is located in northern Arizona near the north rim of the Grand Canyon in the American Southwest (Fig. 1). This lava flow is part of a larger volcanic landscape known as the Uinkaret Lava Field. The human connections and usage of this unique landscape are at the center of a heritage environmental communication debate. This debate is centered on creating meaning regarding places, objects, and landscapes, and it shapes how people see and value heritage. It also can bring to the forefront the conflicting views on heritage places and landscapes (Hanson \& Cox, 2015). This chapter highlights the debate between the Southern Paiute tribes and the archeologists who conducted field surveys in the area over how and when the Little Springs Lava Flow was used. This debate affects which heritage interpretation contributes to heritage management decisions and cultural displays and signage.

K. Van Vlack $(\bowtie)$

Living Heritage Research Council, Cortez, CO, USA

(C) The Author(s) 2022

A. Sjölander-Lindqvist et al. (eds.), Anthropological Perspectives on

Environmental Communication, Palgrave Studies in Anthropology

of Sustainability, https://doi.org/10.1007/978-3-030-78040-1_2 


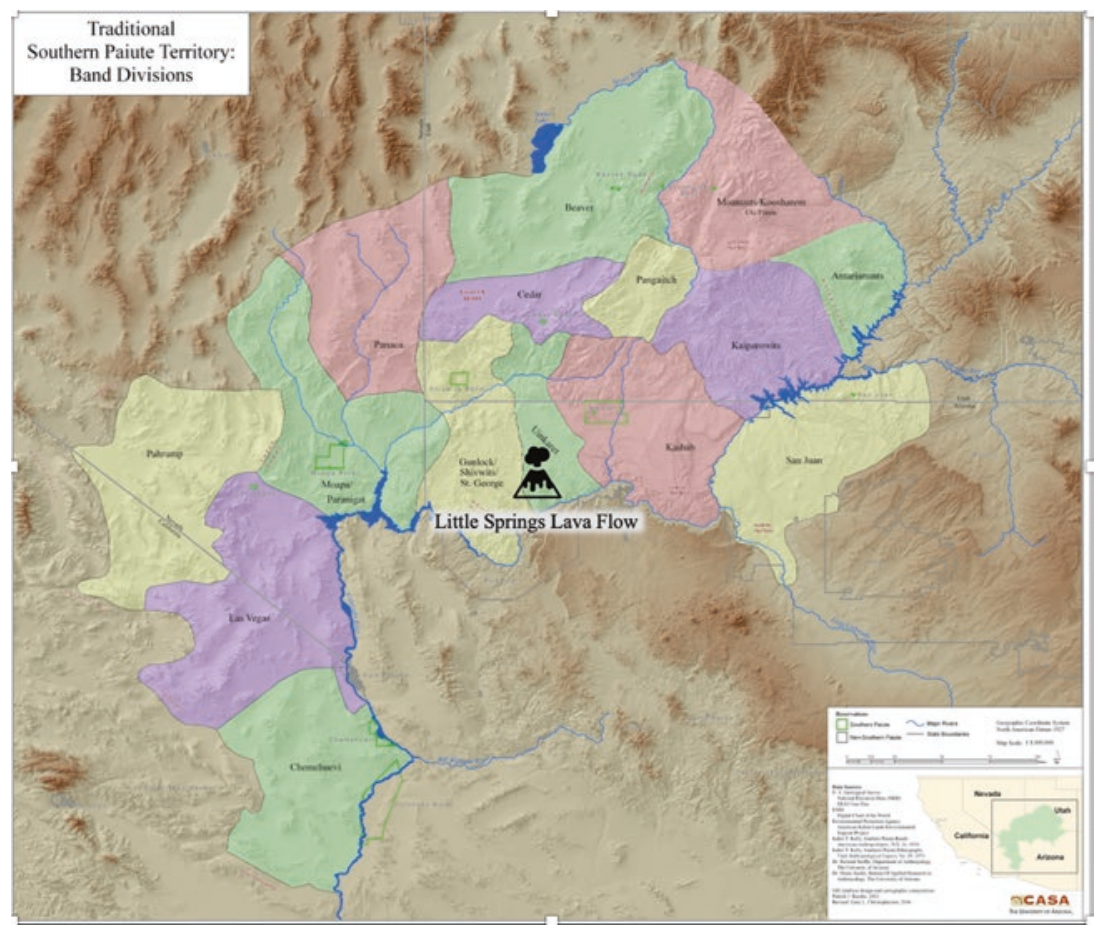

Fig. 1 Little Springs Lava Flow located within traditional Southern Paiute territory. (This image used with permission of Richard Stoffle)

This chapter brings forth a particular environmental communication issue that has been noted by Joosse et al. (2020). They note that representing marginalized voices is key for change-oriented and engaged environmental communication scholarship and that this type of research can offer different perspectives on contested environmental issues (Joosse et al., 2020; Milstein \& Kroløkke, 2012). Voices are excluded from discussions of heritage and environmental conservation due to gender, social class, race, and lack of ability to verbally speak, and this is the result of power relations that have become deeply entrenched in society. Joosse et al. (2020) pointed out that environmental communication scholars in recent years have highlighted this issue and note that researchers aim to give voice to those who have been historically excluded but there is a risk of silencing perspectives and experiences that do not fit the aims of the 
research process and goals. When environmental communication scholars challenge and counter flawed representations, they risk dealing with the long-term effects of discursive colonialism, which is the reproduction of interests of powerful state actors through various forms of knowledge and scholarship (Mohanty, 1984).

In this era of decolonization and self-determination, Southern Paiute people, like indigenous peoples around the world, are working toward reclaiming the telling of their histories and their cultures. Indigenous peoples are positioning themselves to put forth certain parts of their cultures that have been ignored or misinterpreted by heritage researchers and land managers to combat stereotypes and rhetoric that disconnect them from their traditional lands. In some places, indigenous peoples have been successful in this process, such as the Maori of New Zealand (Smith, 2012). However, in other places like the United States, it is an ongoing struggle. In the Great Basin and Colorado Plateau region of the United States, Southern Paiute people have long expressed a need to share various elements of their culture to provide an alternative perspective to counter the stories presented by archeologists and some cultural anthropologists.

\section{Methodology}

This analysis is based on multiple Native American cultural resource studies in the Grand Canyon-Arizona Strip region. The data used in this chapter was collected during two federally funded Native American ethnographic studies. The first project was funded by the Bureau of Land Management (BLM), Arizona Strip Field Office in 2003. This study focused on understanding Southern Paiute cultural landscapes, places, and cultural resources throughout the Arizona Strip (Stoffle et al., 2005). During this study, tribal representatives from the Kaibab Band of Paiute Indians along with ethnographers from the University of Arizona (UofA) first visited the Little Springs area. During this time a recommendation was made for a second study focused solely on Southern Paiute connections and interactions with the Little Springs Lava Flow.

Based on those tribal recommendations, the second follow-up study was funded in 2012 by Grand Canyon-Parashant National Monument, which is jointly managed by the BLM and the National Park Service. This follow-up study allowed for the UofA research team to bring many of the same tribal representatives who took part in the original field visits in 2003 
back to the Little Springs area for a more in-depth examination of the lava flow and surrounding cultural resources (Van Vlack et al., 2013).

During both studies, the UofA team conducted interviews with tribal representatives using survey instruments that had been developed and refined over the past 25 years with the assistance of official tribal representatives, and these forms have been approved by participating tribal governments. These instruments have been administered to Indian people during at least 20 different projects since 1997. This equates to over one thousand interviews with Indian people.

During the 2012 Little Springs study, the UofA team used two survey instruments to interview tribal representatives- the Site Evaluation Form and the Cultural Landscape form. Each one of the forms provides Indian people an opportunity to discuss the cultural importance of a place and how it is connected to other areas within their traditional territory and the surrounding local landscape. In total 58 interviews were conducted in the Little Springs area during the two studies.

\section{Previous Research}

There are only a few published studies that attempt to understand the human connections and uses of this unique landscape. Most have been archeological studies (Elson \& Ort, 2006; Hintzman, 2012; Ort et al., 2008a, 2008b). These studies have used the available archeological data and information on the volcanic eruption to interpret the American Indian lifestyles and behavioral responses that occurred before, during, and after the Little Springs event. Two ethnographic studies have been published involving the Kaibab Band of Paiute Indians; these reports documented the Southern Paiute interpretation of the lava flow and how it is important to the larger Grand Canyon landscape (Stoffle et al., 2005; Van Vlack et al., 2013).

Most of the previous accounts agree that Indian people used the Uinkaret Volcanic Field area for long periods before the Little Springs volcanic event. Many scholars also agree that the Little Springs event was special because Indian people came to interact with a hornito in the active lava flow and made sherd rocks, and that Indian people made up to five miles of trails on the two lava flows and hundreds of round low wall structures. A rift occurs, however, when archeologists and Southern Paiutes answer the questions of who the Indian people who used this area were and for what purpose the Indian people used the lava flow. 
The Southern Paiute interpretation of the significance of the Little Springs Lava Flow and the Uinkaret Volcanic Field varies greatly from the published archeological interpretations. While Southern Paiutes and archeologists are in agreement that Indian people constructed the trails and associated structures, the archeologists have maintained that this area was not a ceremonial area as Southern Paiute representatives have stated, but instead it was a place Indian people fled from during the time of the eruption (Elson \& Ort, 2006; Hintzman, 2012; Ort et al., 2008a, 2008b). Archeologists also have argued that Indian people returned to the area post-eruption to live on top of the lava flow for protection. Structures and trails were built for defensive purposes to protect against an unknown enemy.

\section{Southern Paiute Epistemology}

To understand the Southern Paiute perspective on how places and resources are ascribed meaning, it is essential to examine Southern Paiute epistemology. As explained by Liljeblad (1986, pp. 643-644), to the Southern Paiutes, "Puha is everywhere and is a source of individual competence, mental and physical ability, health, and success." This concept is common amongst many different tribes living throughout the western United States such as the Ute, Western Shoshone, Owens Valley Paiutes, Northern Paiute, Mojave, Hualapai, and Havasupai. Puha is a fundamental principle of their epistemologies as well.

Southern Paiute people's belief in a living universe and the notion that everything has Puba shapes how they engage with the landscape and how they approach the act of pilgrimage. This epistemological foundation of Southern Paiute culture is similar to what anthropologist Roy Rappaport (1999, pp. 263-71 and p. 446) calls an ultimate sacred postulate and what social philosopher Alvin Goldman (1999) calls a philosophical primitive.

In Southern Paiute culture, pilgrimage has always focused on the acquisition of Puba, the spiritual transformation of Puba'gants (Southern Paiute medicine men) and building relationships and communities. Puha is derived from Creation and permeates the universe, which resembles a spiderweb. Sometimes it is like a thin scattering; at other times, it occurs where there are clusters of life in high concentrations. Puba exists throughout the universe but varies in intensity from person to person, place to place, element to element, and object to object, similar to how strength differs among humans (Van Vlack, 2012a, 2012b). 
Southern Paiute people maintain that they are the people who were created in and for this cultural landscape. According to Southern Paiute oral history, when the world was formed, the Creator established a set of mutual obligations and responsibilities between Southern Paiute people and this living natural world. As a result, places like volcanoes (Little Springs) need to be interacted with, maintained, and respected.

The Little Springs Lava Flow was an important ceremonial area on the North Rim of the Grand Canyon during the eruption, and Southern Paiutes later returned to construct miles of cinder trails and structures to use in post-eruption ceremonies. It is also estimated that there are at least eight kilometers of trails located on the two lava lobes. Indian people also made hundreds of circular structures along these trails. Evidence suggests that this area became a major destination for Paiutes seeking healing and spiritual enrichment.

\section{Use of the Uinkaret Volcanic Field Before the Little Springs Event (17,000 B.P. to A.D. 1075)}

Most scholars agree that American Indian people were living in the Mount Trumbull and Uinkaret Volcanic Field before the Little Springs volcanic event. Paleo-Indian time-period spears, dart points, and arrow points have been found throughout the Arizona Strip, documenting at least 12,000 years of continuous occupation and use by Indian people. For most of this long period, there was no agriculture north of the Colorado River, so the most important American Indian subsistence activities were hunting, gathering of wild plants, and the management of semi-domestic cultigens.

In the thousands of years before A.D. 500, there is evidence (Rhode \& Louderback, 2007) that Indian people used hundreds of food, medicine, and weaving plants, including amaranth, Chenopodium, Oryzopsis hymenoides, Stanleya pinnat, and Prosopis glandulosa for seed production; Ephedra nevadensis for medicine; and Harpagophytum procumbens for weaving. After using these plants in the same ecosystems for thousands of years, Indian people learned how to encourage and modify many of these plants. Horticulture, defined here as conscious and systematic plant manipulation, thus developed over time due to learning about the physical and biological characteristics of the land and plants. This is often referred to as traditional ecological knowledge (TEK), and experimentation with 
various land-use strategies helped make both land and plants better able to serve Indian people.

There were, however, no major cultigens like corn, beans, or squash north of the Colorado River before this time (A.D. 500) and no evidence of large-scale irrigated agriculture. By A.D. 700, agriculture had diffused throughout the region. Agricultural production in this region rapidly rose in complexity and spatially expanded, corresponding with a climatic shift involving temperature warming and increased rainfall. Pottery production and its elaboration seemed to be directly tied with the more stable community life that is commonly associated with irrigation farming. This emergent lifestyle resulted in a steadily increasing population, a more sedentary lifestyle, the development of social hierarchy, the elaboration of pottery, and probably other elements of culture that do not appear in the archeological record.

The peak of this irrigated-agriculture-based way of life occurred between A.D. 1000 and A.D. 1275. Soon, however, the Little Ice Age, which is currently dated at A.D. 1275 to 1850 and now appears to have been caused by volcanic eruptions elsewhere, marked another major climatic shift. Regional lifeways in the Arizona Strip would rapidly change again due to the onset of the Little Ice Age: by 1300, the climate in the region had drastically changed and the medium-to-small side creeks, which were needed for much of the irrigated agriculture, had dried up, and only the mainstream portion of rivers remained. The UofA team estimates that by 1300 up to $79 \%$ of the preexisting irrigated agriculture in the Kaibab Paiute district was no longer possible because of greater aridity and major changes to weather patterns. As an adaptation to the new climatic conditions, Indian people shifted to a more reliable and mobile lifestyle, which was dependent on the use of natural resources and semi-domestic cultigens, although irrigated agriculture continued to be conducted in the mainstream rivers. Pottery was less useful in this less sedentary lifestyle, so basketry was greatly elaborated. Their focus shifted from pretty pots to beautiful baskets (Van Vlack et al., 2013).

It is unlikely that there were the numbers and kinds of religious specialists in the Mount Trumbull and Uinkaret Volcanic area needed for a reasoned response to the volcanic event. If the latter occurred, then it is possible that religious specialists who were focused on volcanic ceremonies could have been in place near Mount Trumbull at the time of the volcanic event. A second question is "How fast did the eruption event occur?" If the full event occurred over a short period (say a few days or a week) then 
the local people in place at the time would have had little time to make a ceremonial response to the event. If the full event lasted over a long period (say a few months) then time would have been available for runners to be sent to distant Southern Paiute and other Indian residential areas to inform them of the impending event, and they consequently would have had the time to come to the Uinkaret Volcanic Field to discuss appropriate ceremonial responses and carry out these responses during the event itself and after it.

Based on ethnographic current research on the aboriginal water uses of the Kaibab Paiute people, previous research on the aboriginal water uses of the Shivwits/Santa Clara Paiutes (Stoffle et al., 1994), and research on Zion National Park (Stoffle et al., 1997), it is clear that the Uinkaret Volcanic Field was an ecologically marginal area for farming. Instead, for all three Paiute districts, the most productive irrigated agricultural fields were concentrated at much lower elevations along permanent water sources. Each district also had one or more upland or hinterland areas where various activities occurred which could include ceremonies. The irrigated farming areas and primary residential areas for the people of the Uinkaret/Uyu'naits district were along the lower reaches of the Virgin River and its immediate tributaries at an elevation of about 1158 meters. Whatever activities occurred in the Uinkaret/Uyu'naits hinterland, they did so at an elevation of at least 1981 meters.

Given the marginal farming conditions available on the Uinkaret Volcanic Field, it is more likely, based on Southern Paiute cultural logic, that the Uinkaret/Uyu'naits volcanic landscape was primarily used as an important ceremonial landscape rather than a place where many people lived year-round. Those people that did live year-round or most of the year in this landscape were probably Paiute religious leaders and their families who were here to support the conduct of ceremonies related to both this volcanic landscape and powerful places located to the south along the Colorado River. It thus is likely that this hinterland was primarily used for ceremony by a wide variety of religious leaders from many Paiute and other ethnic groups.

Farming in the Uinkaret/Uyu'naits volcanic landscape certainly did occur on a small scale; small number of people who lived in this powerful isolated area for ceremonial purposes practiced some form of farming. The residential Uinkaret/Uyu'naits religious leaders and their families probably farmed here to support themselves and visiting groups seeking places for ceremony rather than the farming here serving as the primary food source for the majority of the Uinkaret/Uyu'naits people. 


\section{Little Springs Volcanic Event and the Southern Paiute Response}

The Southern Paiute interpretation is that when the Little Springs eruption began building up, Paiute Puha'gants began monitoring the seismic activity in the area. The presence of the sherd rocks (pottery pieces fused into volcanic rock) argues for a well-planned and culturally reasoned response to the volcanic event. Such reasoning about the possibility of an eruption event would have to have been conducted over considerable time by religious leaders. The sufficient geological warnings occurred over a lengthy period of an impending eruption, which allowed for local Paiute leaders to send out runners to announce the potential of a coming volcanic event and for Paiute volcanic specialists from great distances to travel to the Mount Trumbull area. After religious leaders were gathered, they would have had time to work together on a reasoned response to a potential volcanic event. This is in contrast with the views of archeologists and other researchers. According to Northern Arizona University volcanologist Michael Ort, the entire Little Springs volcanic event could have happened over a span of as little as a few days to a week (Ort et al., 2008b). If true, this would not have allowed the Indian people to prepare a response in anticipation of the event.

A key factor in determining how Southern Paiute people would have responded to a volcanic event and volcanoes is understanding Paiute environmental knowledge surrounding volcanism. It is known that Southern Paiute people had dozens of kinds of medical specialists and shamans (Kelly, 1939), some of whom used volcanic materials such as obsidian in their religious practices. Omer Stewart (1942, p. 305) documented in the 1930s that Southern Paiute mothers would feed their babies the breast milk that had been placed on a volcanic rock to give the milk and thus the child strength. It is also known that Southern Paiute people, like most Indian ethnic groups in the western US, went to volcanoes to seek knowledge, heal the sick, and to conduct regional and world balancing ceremonies (Stoffle et al., 2015).

Contemporary Southern Paiute people believe that Paiute people possessed sufficient traditional ecological knowledge (TEK) to predict the Little Springs volcanic event and to plan a specific set of behavioral responses once it occurred. The most likely explanation for this is that the Little Springs event happened soon after the massive and lengthy Sunset Crater volcanic eruption. UofA researchers have worked with cultural 
representatives from eight American Indian tribes regarding their interaction with and interpretation of the Sunset Crater event (Toupal \& Stoffle, 2004). While the relative dates for the two events have not been established, it is known that the Sunset Crater event lasted much longer (up to a generation) than the Little Springs event. It is also known from Elson and Ort's research that during the Sunset Crater event, Indian people interacted with the active lava flows and made corn rocks (lava rocks with impressions of corn cobs in them) along edges of the hornito walls (Elson et al., 2002). These rocks then were incorporated into nearby structures, which appear to have been built for conducting ceremonies. Sunset Crater was where these religious innovations first occurred. There at Sunset Crater, and no time before to our knowledge, religious leaders developed this unique manner of interacting with magma flows to produce corn rocks that subsequently were used in making nearby ceremonial structures. This volcanic TEK was the intellectual foundation for the Indian cultural responses to the Little Springs volcanic event.

Parallels can be drawn between the Little Springs volcanic event and the ceremonial activities that occurred at the earlier volcanic episode at Sunset Crater. As with the Little Springs eruption, Indian people came to Sunset Crater to interact with, observe, and study the volcanic event. This type of engagement allowed for religious specialists and leaders from numerous ethnic groups, including Southern Paiute, to gain valuable volcano traditional ecological knowledge (TEK). It can be argued that since Sunset Crater occurred before the Little Springs eruption, Indian people used the knowledge gained at Sunset Crater to safely engage the Little Springs Lava Flow physically and spiritually.

In order to learn about the flowing lava, these religious specialists approached it in the same manner as that described previously for the Little Springs Lava Flow. Instead of using pottery to create new ceremonial items, at Sunset Crater, they used corncobs. The corn was placed on the hornito rims and corn rocks were created when magma that was forced upward landed on the hornito rims and covered the corncobs. These newly created corn rocks were then taken to specially constructed buildings at Wupatki and incorporated into the structure walls for ceremonial purposes (Toupal \& Stoffle, 2004). 
At Little Springs, Southern Paiute religious specialists took the newly formed sherd rocks (Fig. 2) to an area known as the Lightning Site (Fig. 3) to use in ceremonial activities. The Puha'gants incorporated them into the structure found at this site. The walls where the rocks were found face the Northern Lobe. The placement and location of the sherd rocks likely contributed to the site's overall ceremonial function.

The Lightning Site sits on top of a roughly 3.5-million-year-old basalt lava flow. This lava originated from nearby Mount Trumbull, which is located less than two kilometers to the north. The volcanic activity in this area connects places, people, and objects, and the underground magma flows carry Puha and spiritual beings to and from areas in and around the Little Springs Lava Flow. Present at this site are approximately seven to ten room blocks with upright slabs. The room blocks form a C-shape, with a center plaza that faces to the east. The room blocks have two prominent gaps between them in a spot where one would have a view to the west of the Little Springs Lava Flow. Two grinding stones were also found near the room blocks, which may have been used to prepare food items or medicines to be used in ceremonies that involved the sherd rocks.

When Elson and Ort (2006) surveyed this area, they noted that six sherd rocks were found at this site when they surveyed it in the early 2000s. The sherd rocks contain distinct pieces of pottery which were

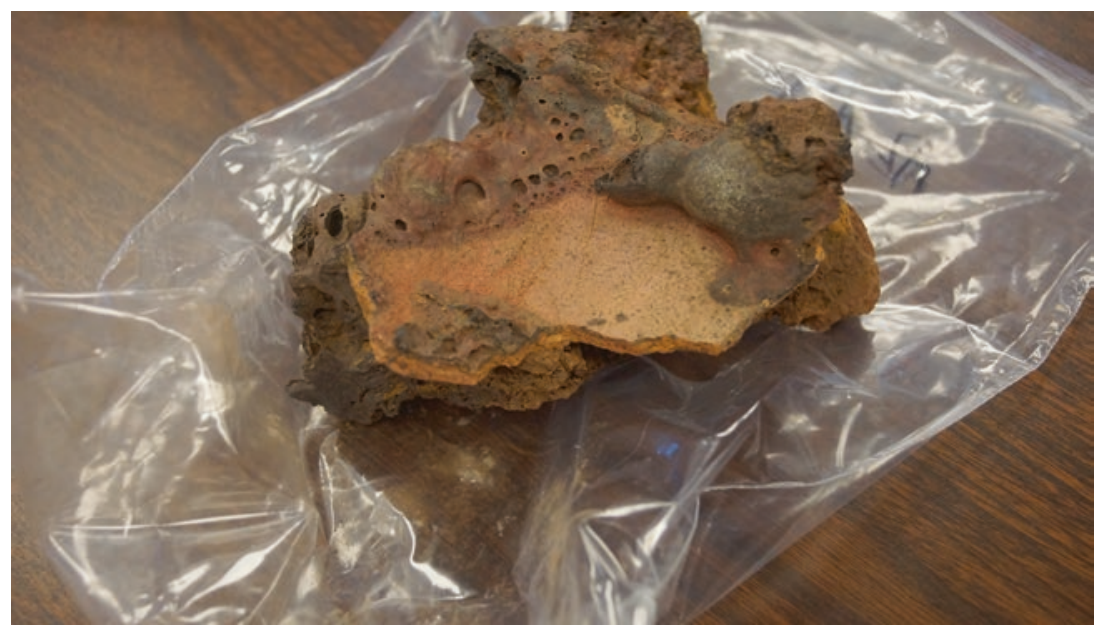

Fig. 2 Sherd rocks. (Photo: Kathleen Van Vlack) 


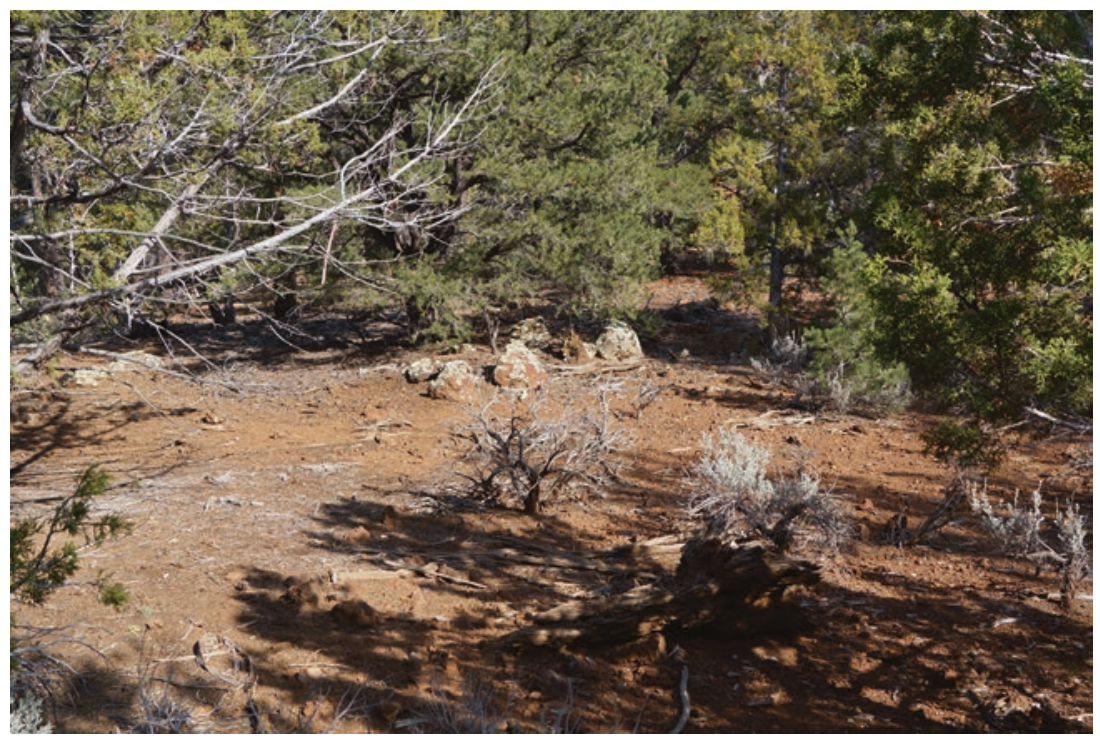

Fig. 3 The Lightning Site. (Photo: Kathleen Van Vlack)

identified to be Hurricane Gray and Hurricane Black-on-Gray. When visiting this site in 2012, the UofA team and Southern Paiute representatives also found other types of pottery at this site, such as Hurricane Black-onGray Corrugated wares. These pottery styles have been dated between A.D. 1050 and 1150, which correspond to the Little Springs volcanic event and immediate post-event ceremonial activities.

Along with the sherd rocks, other unique volcanic rocks were present. These specific rocks differ from the more common volcanic rock in this region. They are lightweight iron-rich basalts that were highly aerated. Along with the sherd rocks, these lighter volcanic rocks had to have been brought into this site from the lava flow.

Research has shown that there are many similarities between the responses to the Sunset Crater and Little Springs volcanic events in terms of powerful religious leaders interacting with active volcanoes and creating ceremonial objects. This is a result of Southern Paiute Puha'gants applying the TEK gained at Sunset Crater to Little Springs. Southern Paiute Puha'gants used their knowledge base and tried a new approach to the ceremonial activity. Instead of corn, Southern Paiute religious leaders used 
whole pots. This change is reflective in that the Paiute response to the Little Springs eruption was a well-thought-out and well-planned cultural response to the Earth being reborn. This cultural knowledge was the intellectual foundation for the Southern Paiute cultural responses to the Little Springs volcanic event.

\section{Post-Eruption: The Initial Southern Paiute Response}

There is extensive evidence of post-eruption Southern Paiute construction activities throughout the entire lava flow. Currently, it is estimated that there are more than eight kilometers of trails across the basalt lava flows. In addition to having brought in burden-basket load after burden-basket load of cinders, Indian people constructed hundreds of low wall and generally round structures along these trails.

It is believed that constructing the trails and structures on the lava flow was very labor-intensive and took a long period of time to build. It is important to remember that 'A'à (rugged Hawaiian-style) basalt lava flows like Little Springs are not smooth but are instead characterized by sharp vertical edges with deep cracks between. There are very few loose basalt stones and almost no cinders available anywhere on the flows. While the surrounding volcanic mountains that define the two valleys do have cinders, these are greatly intermixed with dirt from the forests that have grown upon them. The only abundant source of cinders is the original pyroclastic mountain that was the source of the lava flow. Constructing both trails and structures was thus a significant engineering challenge.

The trails being made from imported cinders occasions an analysis of the level of efforts required to move these cinders to the lava flows. We can begin with the means of transporting the cinders. The only known carrying device available at the time is the Southern Paiute burden basket (Fig. 4). Basket loads would have been transported while held with a tumpline or positioned across the forehead of a man or woman. A typical Southern Paiute burden basket is 76 centimeters tall, 71 centimeters wide in diameter at the top and pointed at the bottom. We estimate that this would hold about 2.8 bushels, or about 100 liters. The known trails have been estimated at eight kilometers. If we look at how many cinders it would take to make a meter of these trails, we estimate it would take three burden-basket loads per meter. Eight kilometers of trail equals 8000 meters. When multiplied by three loads per meter this suggests that about 24,000 round trips were needed to make these trails. 


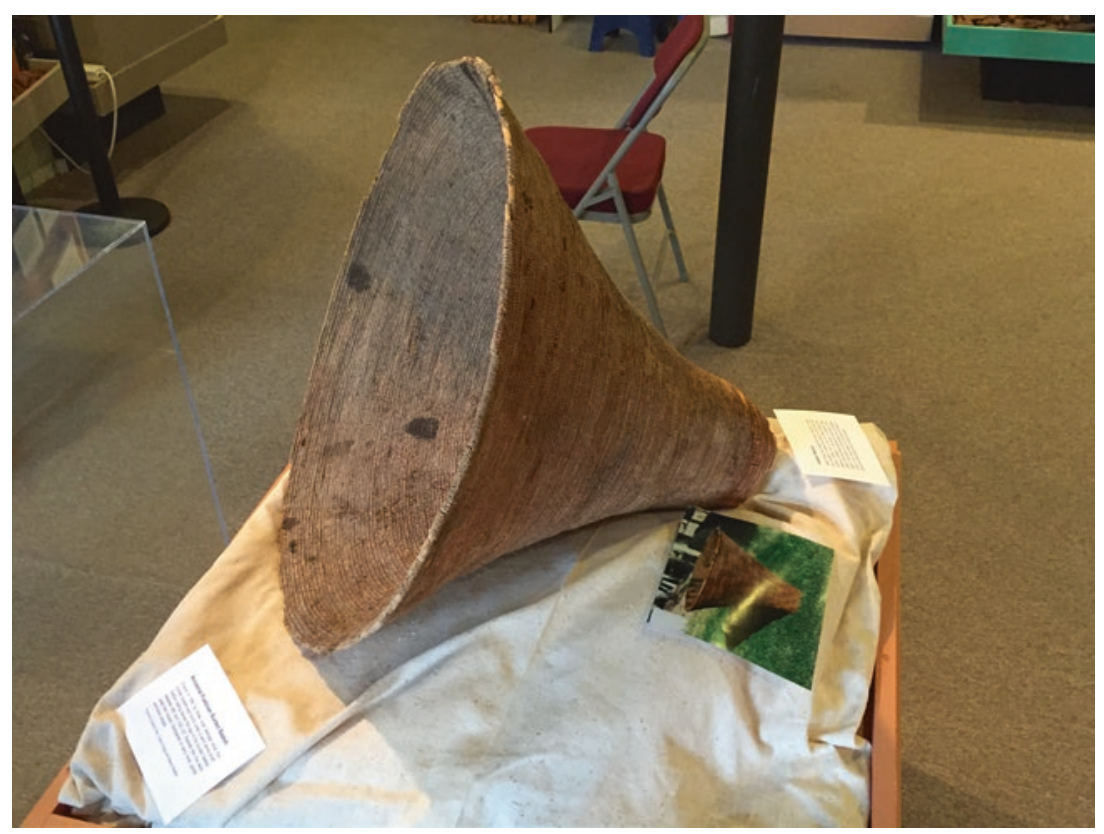

Fig. 4 Southern Paiute burden basket. (Photo: Kathleen Van Vlack \& Richard Stoffle)

Over 100 structures were built directly on the basalt lava flow and thus would have involved an unknown number of man-hours to build the walls from loose basalt blocks, most of which would have to have been carried in from elsewhere on the lava flow. The rockfill in the structures would have involved the same kinds of efforts as were needed for the construction of the trails. We estimate that about 1200 liters of fill would be needed per structure at a minimum. It thus would take about 12 burden-basket loads of cinders to make each structure usable. We estimate that 100 structures would involve about at least 1200 round-trip basket loads.

When the basket loads for the construction of both the trails and the associated structures are added together, it totals an estimated 25,200 round trips. In addition to the labor needed to construct the walls of the various structures, it can be assumed that the walls were complemented with sidewalls and conical roofs made from plants. More labor was needed to plan and supervise this elaborate series of trails and low walled 
structures on the two lava flows. All persons involved in the construction would have been fed and attended to by a support community. The constructions on the Little Springs Lava Flow were a major undertaking, but perhaps of more import for the cultural assessment of the area is where the idea for such construction came from and why this cultural innovation was made at all.

The only published theory for interpreting the trails and low walled structures on the two lava flows is by Mark Elson and Michael Ort (Elson \& Ort, 2006). Their theory is that after the lava flows cooled, Indian people came under attack by others. Their response to this attack was to build a place to hide in the lava flows. Afterward, when they were threatened by attack, they could retreat to the lava flows for protection.

The Southern Paiutes have rejected Elson and Ort's theory and provided their own alternative theory. Southern Paiutes stipulate that this area had been used since time immemorial for ceremonies and healing. The Little Springs event both validated that previous cultural interpretation and added new Puha to the area. Indian people who experienced the Little Springs Lava Flow interpreted it as a gift of Mother Earth. The eruption and subsequent flow involved the emergence of Puha from the Earth in this special place. The eruption was a symbolic gift validating the power and cultural importance of this landscape. The only possible response for the people experiencing this gift was to lay the foundation for directly interacting with the volcano and its lava flow. An enormous amount of effort, under the guidance of religious leaders, was thus expended to provide access to special areas on the flow and structures so that religious people were able to spend time interacting with the flows and their Puha. It is assumed that the construction plans and their implementation occurred soon after the eruption event and took about a generation of concerted efforts. It is also assumed that this was a project that involved all of the Southern Paiute people who would attend to the ceremonial needs of this important spiritual area, as they did with other such areas.

On top of the lava flows located along these trails and throughout the flows are about 100 structures. This number is a very conservative estimate. Recent archeological survey work suggests that there may be as many as 250 structures on the lava flow (Hintzman personal communication). The typical structure is approximately four meters ( $\sim 13$ feet) across. Some are smaller and others much larger. Most structures today have evidence that their bottoms were filled with cinders and perhaps dirt. We estimate that a layer of fill up to 0.3 meters thick was needed to make the structures usable. 


\section{Post-Eruption Ceremonies: Little Springs Pilgrimage}

After the volcanic event ended, Southern Paiute volcano Puha'gants continued to use this area for ceremony. The lava flow became a pilgrimage destination place for those seeking Puha (the energy force found in all elements of the universe) from the volcano and the lava flow. They followed a pilgrimage trail that led them to various shrines for prayers and rituals to prepare them for interaction with the lava flow and receive its knowledge and power (Van Vlack, 2012a, 2012b, Van Vlack et al., 2013). When the Puha'gants reached the northern lobe of the lava flow, they visited the hot spring. They used the hot spring for ritual cleansing and purification, which is a necessary step in the pilgrimage process (Van Vlack, 2012a, 2012b). The Puha'gants needed to have themselves cleaned of impurities and sickness, which could tamper with the ceremonial activities that occurred on top of the flow. During the post-volcanic-event pilgrimage, the shamans traveled along the trail that led them to an area known as Coyote's House.

\section{Hot Spring at the Northern Lobe of the Little SPRINGS LaVA Flow: UnUVATS}

As pilgrims traveled south from Paiute Cave toward Mount Trumbull, the valley becomes bounded by high volcanic mountains and flows. These types of constrictions are important physical attributes to Southern Paiute pilgrimage trails. In Southern Paiute culture, narrow or constricted spaces influence cultural meaning and affect the movement of natural elements like wind and water. Pilgrimage trails such as this one to Little Springs pass through or near these narrow spaces because these are areas where Puha converges and collects, like how water will pool in constricted places. As a trail passes through these types of locations, a pilgrim can experience and draw upon the power of the area as he or she progresses on the journey.

As pilgrims traveled southward, they reached the northern end of the Little Springs Lava Flow to the hot springs. According to tribal representatives, the name for this spring in Southern Paiute is Unuvats, which means "volcanic rock spring." The Northern Lobe hot spring was formed 
from local volcanic activity in the area. When the Little Springs Volcano erupted, the flowing lava altered the area's hydrology. As the lava moved across the landscape, it followed existing surface drainages, blocking them and forcing the creation of new surface water flow patterns. The lava flows are very permeable, allowing for the water to be stored in naturally occurring reservoirs and recharge the water table.

The Puha that emerges from a place can be used to heal individuals and small groups (Miller, 1983). The power of the place is often supplemented by the presence of medicinal and ceremonial plants, minerals, viewscapes, and another natural phenomenon. These elements and artifacts are made more powerful by their proximity to powerful places.

Before entering a hot spring, Indian people would speak to the spirit of the spring, introducing themselves and explaining why they were visiting (Stoffle et al., 1997). Southern Paiute elders have stated that hot springs were also used by shamans for ritual purification before visiting sacred caves, valleys, or other spiritual locations. Such purification was necessary to prepare the mind and body for safe and proper interaction with spiritual beings (Stoffle et al., 1997; Van Vlack, 2012a, 2012b).

There are remnants of numerous stone structures located at the base of the flow near the spring. These structures are believed to be associated with ceremonial activity and purification at the hot spring for Puha'gants or shamans before visiting the lava flow. The Puha'gants most likely used structures in correspondence with the hot spring, and this was an intense period of prayer and preparation.

\section{The Northern Lobe of the Little Springs Lava Flow}

The Northern Lobe of the Little Spring Lava Flow (Fig. 5) is found at approximately 2018 meters (6620 feet) in elevation and is situated in a valley between Mount Trumbull to the northeast and Mount Logan to the southwest. The previously discussed hot spring is found at the base along the flow's northern edge. The pyroclastic cone responsible for creating the Little Springs Lava Flow is located approximately 1.92 kilometers (1.20 miles) to the south of the Northern Lobe's northern edge.

Puha'gants started their ceremonial activities at the Northern Lobe by first purifying themselves at the hot spring. From there they climbed up onto the lava flow (Fig. 6). Along the northern edge, there are two primary trails. The trail closest to the hot spring leads directly to a hornito. It is believed that Southern Paiute religious specialists used this trail to 


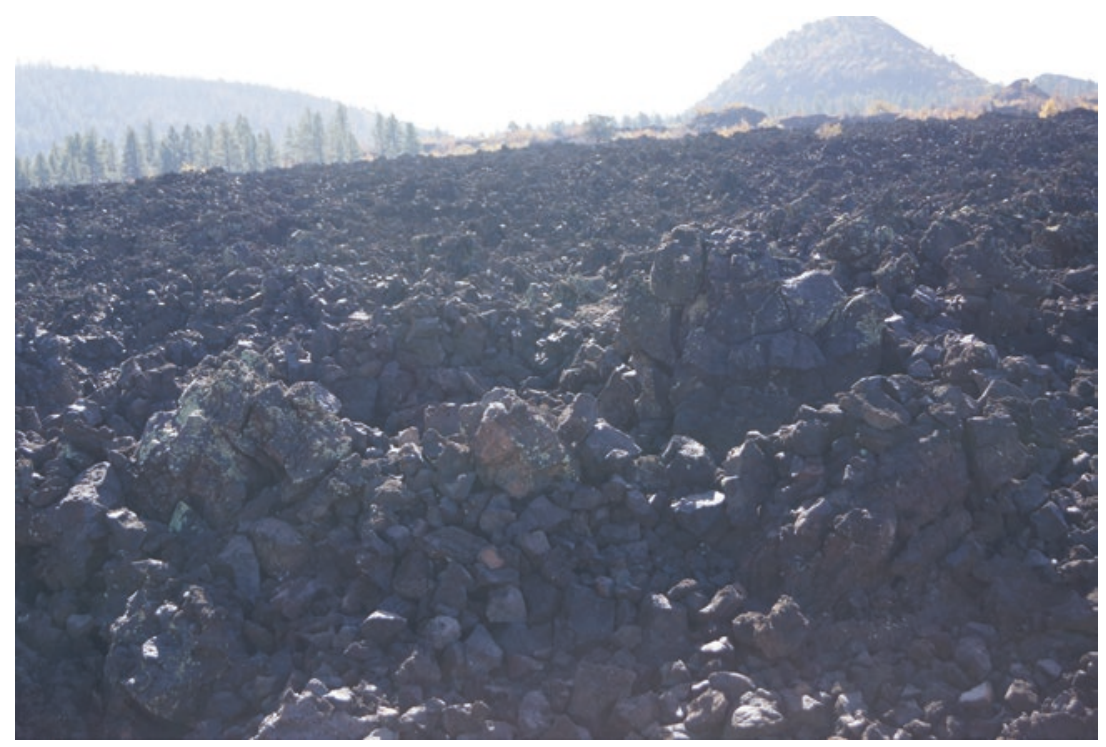

Fig. 5 The Little Spring Lava Flow with structures in the foreground. (Photo: Kathleen Van Vlack)

interact with the lava flowing up from the hornito to create the sherd rocks. The second trail is believed to be associated with the pilgrimage to the center of the Northern Lobe to an area known as Coyote's House.

The trail network across the Northern Lobe involved extensive construction following the volcanic eruption. Indian people began to build a series of trails and ceremonial structures on the lava bed. Construction involved bringing in cinders from the Little Springs Volcano itself in burden baskets in approximately 25,200 round trips. This estimate accounts for eight kilometers (4.97 miles) of trails and a conservative estimate of 100 structures. UofA ethnographers and Southern Paiute representatives noted at least ten distinct circular structures ranging from three to six meters wide. Cinders were used in wall construction and floor fill. Indian people also used the cinders to fill in the hornito bottom to create a stable floor base, so religious specialists could be inside the hornito during posteruption ceremonial activity. 


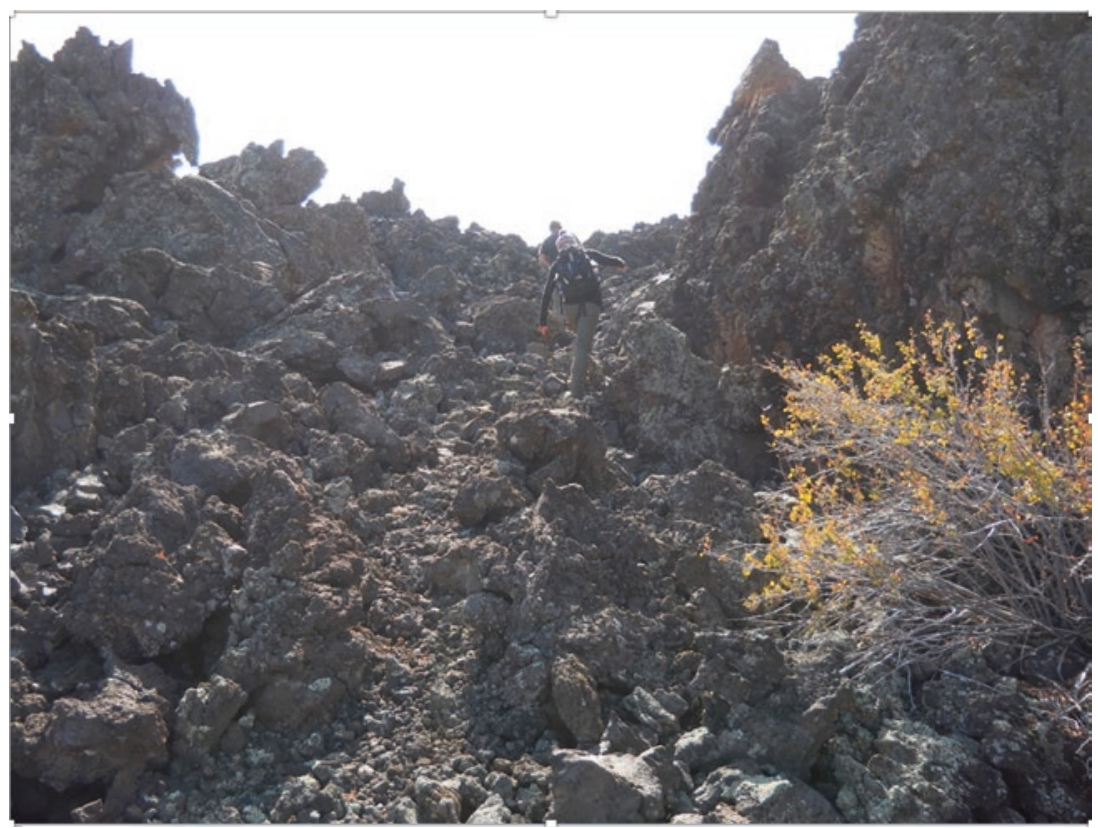

Fig. 6 Trail leading to the Northern Lobe. (Photo: Kathleen Van Vlack)

\section{Coyote’s House}

The other trail leads to an area on the lava flow referred to as Coyote's House (Fig. 7) or Coyote Pocket. This feature is a large volcanic outcrop that has a subsurface cave and unique vegetation. Along the trail to this location, many pieces of pottery were found. Additionally, numerous naturally occurring water catchments are found in this part of the lava flow. A large bowl fragment was found sitting above one of the largest water catchments at this site.

During ethnographic interviews with Southern Paiute tribal members, they discussed how the Northern Lobe was a ceremonial destination place used by special types of medicine men or shamans. In order to understand how and why Southern Paiute shamans came to the Little Springs area for ceremony and Puha acquisition, it is necessary to examine the relationship between religious practitioners and Puha. Shamans are predisposed to have certain kinds of Puha, which they can use to accomplish certain 


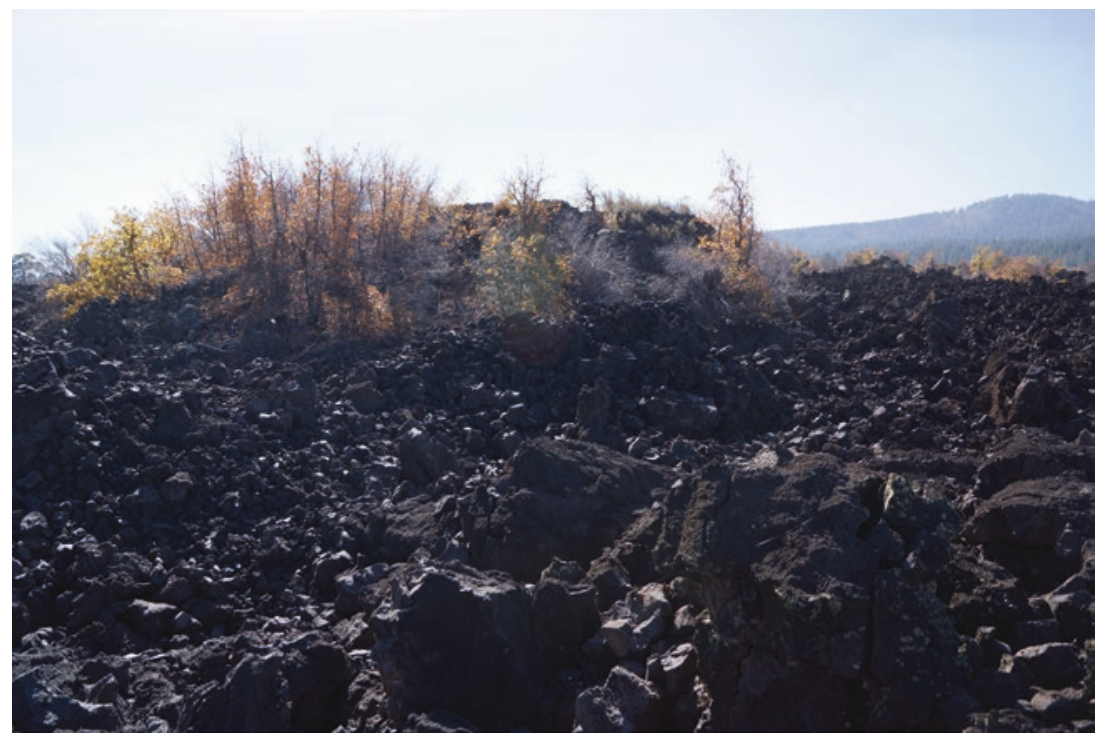

Fig. 7 Coyote's House. (Photo: Kathleen Van Vlack)

things that may or may not benefit Southern Paiute society. Shamans gain access to additional Puha by visiting special places and through the acquisition of spirit helpers. Sometimes, they use their Puha to bring people, communities, or the world back into balance. During these times, the shamans are portals through which their Puha and the Puha of their spirit helpers combine during the ceremony to achieve a cure.

The Puha'gants left offerings at these water catchments, and they prayed and sought the proper permissions to enter into Coyote's House. Inside this unique geologic structure is a large cave, which Puha'gants would enter for ceremony. This area could have served as a portal where the Puha'gants left this dimension of the universe and entered into another one to acquire Puha associated with volcanism. The power and knowledge the Puha'gants gained during this portion of the pilgrimage were used in ceremonies in their home communities or at other ceremonial areas, such as places in the Grand Canyon. 


\section{Discussion: Navigating the Epistemological Divide}

At the crux of this environmental communication debate between archeologists and Southern Paiutes is the question of who can speak about the past and who is considered the authority or expert. As we can see from the analysis, the Southern Paiute people understand the Little Springs Lava Flow to be intimately connected with their history and their cultural heritage. They have oral histories linking the topography of the landscape to their history and their beliefs. The origin stories of the Southern Paiutes stand in conflict with the findings and interpretation made by archeologists in the same area. Great Basin and Colorado Plateau archeologists argue that Southern Paiutes are recent arrivals in the area, and either they moved into a land emptied by the migration of its former inhabitants, or those inhabitants died out where they had lived for thousands of years. These arguments suggest that the Paiute were a replacement culture characterized by nomadic wandering and hunting and gathering. Either argument can be categorized as a component of the Numic Spread Hypothesis (Lamb, 1958), which archeologists use to distance and disconnect Paiute people from their homelands and cultural resources. Archeologists who conducted research in and around the Little Springs Lava Flow have brought forth this hypothesis in their analysis, and thus they have attempted to shut the Paiutes out of the story.

The Kaibab Band of Paiute Indians has formally rejected all aspects of the Numic Spread Theory since the theory's rise to prominence in Great Basin and Colorado Plateau archeology. The tribe, along with the other seven Southern Paiute tribes, has stipulated that the Southern Paiute people have lived in their traditional lands from time immemorial (legal term), or since the time when they were placed on these lands by the Creator (Stoffle et al., 2004; Southern Paiute Advisory Committee, 2011). They have also stipulated that they are the ones who used and interacted with the Little Springs Lava Flow during and after the eruption.

As a heritage issue and an environmental communication issue, how does one reconcile the stark differences in interpretation of how the Little Springs Lava Flow has been used since its eruption? The Kaibab Paiutes, like many other indigenous groups, have the right to tell their own story and the right to determine how their past should be investigated and shared with the public. This issue is the result of two vastly different epistemologies, and often the differences cannot be dealt with in a manner that benefits both sides. One solution which has proven to be successful 
throughout the U.S. National Park Service is to move away from the desire for only one ultimate story/one interpretation and allow for multiple voices in an effort to settle the environmental communication issue and cultural heritage dispute. This allows the Kaibab Paiutes to share their perspectives and cultural understandings of Little Springs Lava Flow, and it would also allow the archeologists to present their interpretations as an alternative way of understanding. When tribes like the Kaibab Paiutes are included as partners in the decision-making process, they will bring forward their cultural knowledge as a valuable tool in heritage management and heritage conservation.

Acknowledgments Dr. Van Vlack wishes to express her sincere gratitude to all of the Southern Paiute people who participated in the study. She expresses her heartfelt thanks to them for taking time away from their families and busy schedules to share their knowledge of traditional life and cultural resources in the Arizona Strip. Without the collaboration and participation of Southern Paiute elders and experts, this study could not have been done. Dr. Van Vlack also wants to thank the Bureau of Land Management Arizona Strip Field Office and Grand Canyon-Parashant National Monument for providing the funding and agency support for this research.

\section{REFERENCES}

Elson, M., Ort, M., Hesse, J., \& Duffield, W. (2002). Lava, Corn, and Ritual in the Northern Southwest. American Antiquity, 67(1), 119-135.

Elson, M. D., \& Ort, M. H. (2006). The Little Springs volcanology and archaeology project, Grand Canyon-Parashant National Monument, Arizona, investigators final report. Western National Parks Association.

Goldman, A. (1999). Knowledge in a social world. Oxford.

Hanson, A., \& Robert, C. (2015). The Routledge Handbook of Environmental Communication. New York, Routledge.

Hintzman, M. (2012). Take me to Lava Town: The archaeology of the Little Springs Lava Flow. Master's thesis, Flagstaff, Arizona, Northern Arizona University.

Joosse, S., Powell, S., Bergeå, H., Böhm, S., Calderón, C., Caselunghe, E., Fischer, A., Grubbström, A., Hallgren, L., Holmgren, S., Löf, A., Nordström Källström, H., Raitio, K., Senecah, S., Söderlund Kanarp, C., von Essen, E., Westberg, L., \& Westin, M. (2020). Critical, engaged and change-oriented scholarship in environmental communication: Six methodological dilemmas to think with. Environmental Communication, 14(6), 758-771. https://doi.org/10.108 0/17524032.2020.1725588 
Kelly, I. (1939). Southern Painte Shamanism. Berkley: University of California Press.

Lamb, S. (1958). Linguistic prehistory in the Great Basin. International Journal of American Linguistics, 25, 95-100.

Liljeblad, S. (1986). Oral tradition: Content and style of verbal arts. In W. L. d'Azevedo (Ed.), Handbook of North American Indians, vol. 11: Great basin (pp. 641-659). Smithsonian Institution.

Miller, J. (1983). Basin religion and theology: A comparative study of power (puha). Journal of California and Great Basin anthropology, 5(1,2), 66-86.

Milstein, T., \& Kroløkke, C. (2012). Transcorporeal tourism: Whales, fetuses, and the rupturing and reinscribing of cultural constraints. Environmental Communication, 6(1), 82-100. https://doi.org/10.1080/1752403 2.2011 .642079

Mohanty, C. T. (1984). Under western eyes: Feminist scholarship and colonial discourses. Boundary, 2(12/13), 333-358. https://doi.org/10.2307/302821

Ort, M. H., Elson, M. D., Anderson, K. C., Duffield, W. A., Hooten, J. A., Champion, D. E., \& Waring, G. (2008a). Effects of scoria-cone eruptions upon nearby human communities. Geological Society of America Bulletin, $120(3 / 4), 476-486$.

Ort, M. H., Elson, M. D., Anderson, K. C., Duffield, W. A., \& Samples, T. L. (2008b). Variable effects of cinder-cone eruptions on prehistoric agrarian human populations in the American Southwest. Journal of Volcanology and Geothermal Research, 176(3), 363-376.

Rappaport, R. (1999). Ritual and religion in the making of humanity. Cambridge University Press.

Rhode, D., \& Louderback, L. (2007). Dietary plant use in the Bonneville Basin during the terminal Pleistocene/Early Holocene transition. In K. Graf \& D. Schmitt (Eds.), Paleoindian or paleoarchaic? Great Basin human ecology at the Pleistocene-Holocene transition (pp. 231-247). University of Utah Press.

Smith, L. (2012). Decolonizing methodologies: Research and indigenous people. Zed Books Ltd..

Southern Paiute Advisory Committee (SPAC). (2011). Southern Paiute Ethnographic Study for the Lake Powell Pipeline EIS: Report Regarding Study Plan 23-Ethnographic Resources, for Kaibab Band of Paiute Indians, San Juan Southern Paiute Tribe, and Paiute Indian Tribe of Utah, for the Lake Powell Hydroelectric System. Report Prepared for Utah Division of Water Resources. Submitted on Behalf of the Kaibab Band of Paiute Indians, Paiute Indian Tribe of Utah, and the San Juan Southern Paiute Tribe. Bureau of Applied Research in Anthropology, University of Arizona, Tucson AZ.

Stoffle, R., Arnold, R., Frank, M., Cornelius, B., Miller, L., Charles, J., Kane, G., Ruuska, A., \& Van Vlack, K. (2015). Ethnology of volcanoes: Quali-signs and the cultural centrality of self-voiced places. In L. Scheiber \& N. Zedeno (Eds.), 
Engineering mountain landscapes: An anthropology of social investment (pp. 99-111). University of Utah Press.

Stoffle, R., Chmara-Huff, F., Van Vlack, K., \& Toupal, R. (2004). Puha flows from it: The Spring Mountains cultural landscape study. Bureau of Applied Research in Anthropology, University of Arizona.

Stoffle, R., Halmo, D., Olmstead, J., \& Dobyns, H. (1994). Uatah (fields where we plant all the time): Shivwits Southern Paiute water use along Tunakwint, the Santa Clara River. University of Michigan.

Stoffle, R., Van Vlack, K., Carroll, A., Chmara-Huff, F., \& Martinez, A. (2005). Yanawant: Paiute places and landscapes on the Arizona Strip-Volume one of the Arizona Strip landscapes and place name study. Bureau of Applied Research in Anthropology, University of Arizona.

Stoffle, R. W., Halmo, D., \& Austin, D. (1997). Cultural landscapes and traditional cultural properties: A Southern Paiute view of the Grand Canyon and Colorado River. American Indian Quarterly, 21(2), 229-250.

Toupal, R., \& Stoffle, R. (2004). Traditional Resource Use of the Flagstaff Area Monuments. Prepared for the National Park Service Cooperative Agreement Number 1443CA1250-96-006. Tucson, AZ: Bureau of Applied Research in Anthropology, The University of Arizona.

Van Vlack, K., Stoffle, R., Pickering, E., Brooks, K., \& Delfs, J. (2013). UnavNuquaint: Little Springs Lava Flow ethnographic investigation. Prepared for Grand Canyon Parashant National Monument. Bureau of Applied Research in Anthropology, University of Arizona.

Van Vlack, K. A. (2012a). Puaxant tuvip: Powerlands Southern Paiute cultural landscapes and pilgrimage trails (Order No. 3505682). Available from Publicly Available Content Database. (1013831696). https://lib-proxy.sunywcc.edu/ login?url=https://lib-proxy.sunywcc.edu:2077/dissertations-theses/puaxanttuvip-powerlands-southern-paiute-cultural/docview/1013831696/ se- 2 ? accountid $=14174$

Van Vlack, K. A. (2012b). Southern Paiute pilgrimage and relationship formation. Ethnology, 51(2), 129-140. 
Open Access This chapter is licensed under the terms of the Creative Commons Attribution 4.0 International License (http://creativecommons.org/licenses/ by $/ 4.0 /)$, which permits use, sharing, adaptation, distribution and reproduction in any medium or format, as long as you give appropriate credit to the original author(s) and the source, provide a link to the Creative Commons licence and indicate if changes were made.

The images or other third party material in this chapter are included in the chapter's Creative Commons licence, unless indicated otherwise in a credit line to the material. If material is not included in the chapter's Creative Commons licence and your intended use is not permitted by statutory regulation or exceeds the permitted use, you will need to obtain permission directly from the copyright holder. 